\title{
Evaluating Biophysical Attributes of Environmentally Degraded Landscapes in Northern Ethiopia using LANDSAT ETM data and GIS ${ }^{1}$ Gala T. S., ${ }^{1}$ Pazner $M$ and ${ }^{2}$ Beyene $S$.
}

doi: 10.4314/ejesm.v4i1.1

\begin{abstract}
Biophysical attributes of environmentally degraded landscapes in Adwa district, northern Ethiopia, were evaluated using LANDSAT ETM data and GIS. Satellite remote sensing (RS) has captured the spatial distribution and variability of Adwa land covers (75\% classification accuracy, 73\% Kappa statistic). GIS-based analysis of degraded land's biophysical attributes has revealed associations between land-cover types, landform elements and major soils groups in the district. Agricultural farms were located closer to human settlements, while woodlands furthest away from settlements. Moreover, wooded croplands were found between arable and woodlands, indicating encroaching human activities through agricultural expansion. Forests and woodlands were dominant on high mountains, steep slopes and depressions, while degraded shrublands and scrublands were prominent on Leptosols and on dissected uplands and hills. On the other hand, agriculture was prominent on rolling hills and uplands, concave-shaped foot-slopes, and on the soils of the district characterized as Fluvisols and Vertisols. This study provides base-line information and add to land cover knowledge for this and similar regions. Additionally, it has identified associations among biophysical attributes in degraded Ethiopian highlands have important management implications for both under-developed and over-utilized areas.
\end{abstract}

Keywords: Land cover, land degradation, soil erosion, land rehabilitation, deforestation, Ethiopian highlands

\section{Introduction}

- 1 nvironmental degradation is one (Esser et al.; 2002; Bishaw, 2001). According to several reports on Ethiopian forests covered approximately $40 \%$ of the land a century ago but now has shrunken to only 3\% (EFAP, 1994; Berry, 2003). The extensive deforestation has also led to the extinction of various biotas resulting in significant biodiversity loss (Woldu, 1999; Hadgu, 2008). Additionally, accelerated soil erosion on the landscapes without vegetation washed fertile top-soils leading to infertile and shallow soils with poor water storage capacity (Hurni, 1988; Bishaw, 2001). Therefore, the environmental degradation characterized by loss and deterioration of soil, water, forestry and biodiversity is an unfolding crisis in Ethiopia and believed to be a root cause for poor quality of life and food insecurity (Esser et al.; 2002).

Several interacting factors acted as driving forces for environmental degradation in Ethiopia. In the past three decades, cultivation expanded to less suitable lands to meet the food need of the growing population as well as increased the need to use dung and crop residue for energy supplies, rather than nutrient recycling input sources in soils (Berry, 2003) which jeopardized the stability of soils on the landscape (Dubale, 2001). The Ethiopian highland gets high intensity rainfall and its kinetic displaces and washes the soils down-slope, particularly during the early growing season, when the cultivated steepslopes are slightly covered with crops (Nyssen et al.; 2005).

Pursuant to the alarming environmental degradation and the resulting poverty and poor quality of life, government and nongovernmental agencies have implemented various land rehabilitation programs. Afforestation was implemented in rural communities to meet the demands for fuelwood, construction and livestock feed (Dubale, 2001; Bishaw, 2001). In addition, soil and water conservation programs were implemented to improve the productivity of agricultural lands (Hurni, 1988; Bishaw, 2001). These efforts have reduced deforestation and soil erosion rates in some areas (Bewket, 2002) but land degradation is still noticeable in Ethiopia. From approximately 60 million ha of agricultural lands, one-third is experiencing soil erosion and one-sixth of the land is considered eroded (Aynekeulu et al.; 2006). Therefore, much is left to be done, to reverse or stabilize the unfolding crisis of environmental degradation on the Ethiopia highlands.

Satellite Remote Sensing (RS) data can be used to assist land rehabilitation efforts, including through monitoring for policy enforcement purposes. Solar radiation reflectance characteristics of various types of 
land cover have made RS a reliable tool for assessing land covers of the degraded landscapes. The RS also has the advantage of offering large area coverage, large amount of archived land cover data and retrieving land cover information for remote and inaccessible areas. Finally, since it can be integrated with GIS, the spatial and topological associations of land cover types and other physical attributes (soils and landform elements) of degraded landscapes can be studied.

Several studies have implemented remote sensing tools for mapping and monitoring land use land cover of degraded landscapes (Metternicht et al.; 2009; Lu et al.; 2007; Zhang et al.; 2005 and Reina et al.; 1991). Raina et al. (1991) used LANDSAT TM to map the types, extents and degrees of land degradation in an arid region of Jodhpur in India, while $\mathrm{Lu}$ et al. (2007) mapped and monitored environmental degradation and dynamics in western Brazilian Amazon using multi-temporal LANDSAT TM/ETM data. Zhang et al. (2005) was able to map the rate of forest degradation in tropical rainforest, and its topological relations with population density and forest accessibility, using datasets from both the Landsat TM and MSS (Multispectral Scanner System). But none of these researches investigated the relationships among biophysical attributes of degraded landscapes, which are critical in guiding sound decisions with regard to types and magnitudes of land rehabilitation practices an area would require. Therefore, the objectives of this research work were to: a) enumerate land cover types of environmentally degraded landscapes in Adwa district; and b) analyze and interpret the relationship between land cover types and other attributes of the degraded landscapes.

\section{Study Area}

The study area is located in the central administrative zone of the Tigray region (Fig. 1) covering approximately $884 \mathrm{~km}$ square consisting the towns of Adi Abune, Adwa, Werie and Indaba-Tsehama. It has an altitude ranging from 1500 to 2700 meters above sea level (asl) and is located between 38 $48^{\prime} 30.90$ to $39^{\circ} 5^{\prime} 12.59$ East Longitude and $13^{\circ} 51^{\prime} 3.45$ to $14^{\circ} 12 ' 29.13$ North Latitude.

The district receives $882.1 \mathrm{~mm}$ mean rainfall per year (Gemachu, 1977) in a bimodal pattern such that the small rainy season, "Belg" occurs from March to June while the second, big rainy season "Kiremt" occurs from July to September. It varies considerably with elevation; the higher elevations (>1700) receive higher rainfall vis-à-vis the lower elevations $(<1700)$ having direct impact on status and distribution of land cover types (Esser et al.; 2002).

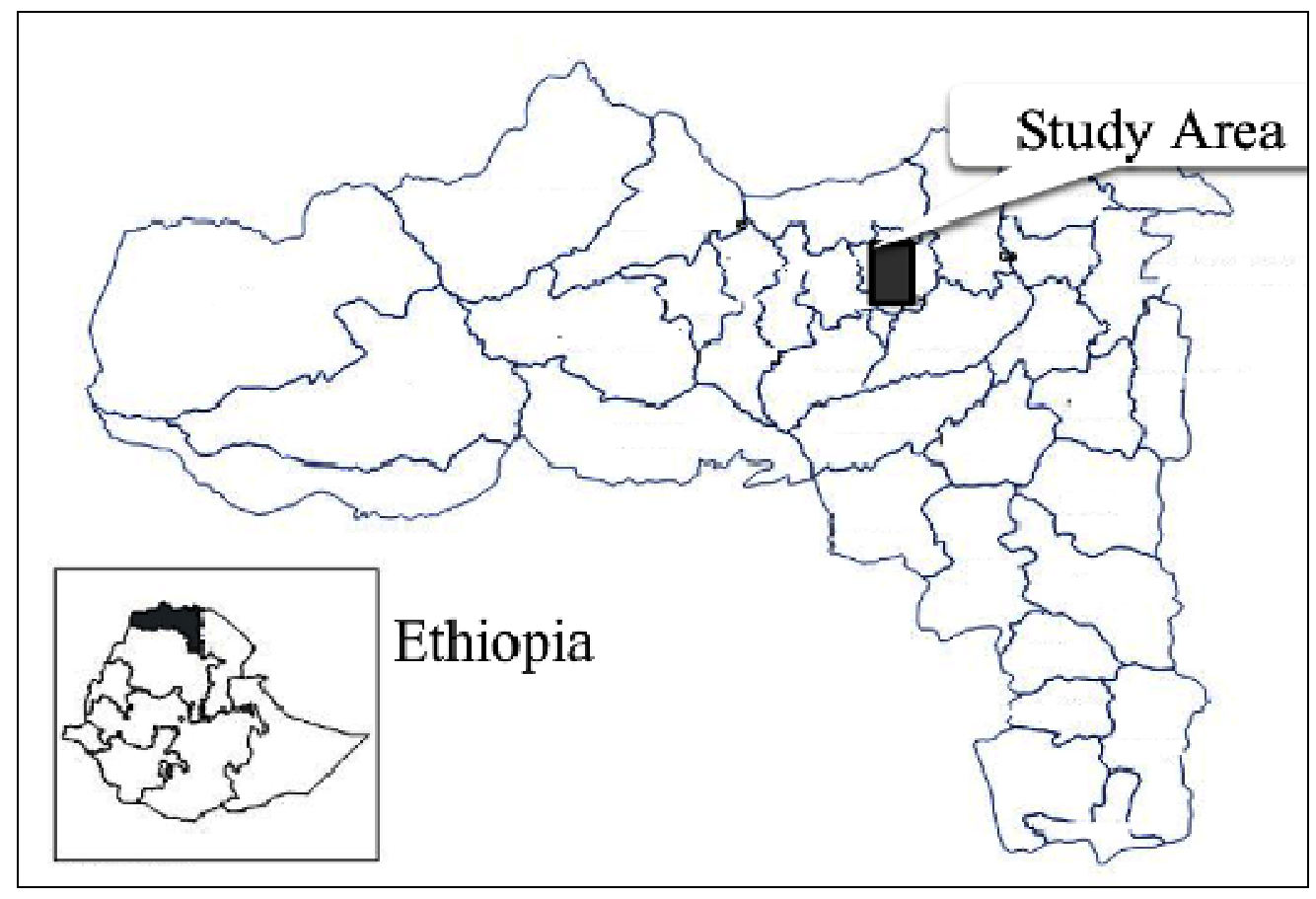

Figure 1: Map of the study area 
Two major land systems: denudation and accumulation systems, characterizes the study area (Machado, 1996).Denudation areas experience net soil erosion (soil loss) and encompass $70 \%$ of the study area, while accumulation areas, which are furnished by erosion products from surrounding higher ground, account for less than $30 \%$ (Feoli et al.; 2002a). Three major landforms: mountains $(>2200 \mathrm{~m}$ asl $)$, hills $(2200-1800 \mathrm{~m}$ asl $)$ and uplands $(<1800 \mathrm{~m}$ asl $)$ and five landform elements (plateaus, escarpments, dome-shaped residuals, dissected and rolling lands) are recognized in the erosional denudation land system (Gala, 2001). Four different landforms elements (concave shaped slopes, alluvial fan, terraces and floodplains) are identified as the accumulation land system (Gala, 2001). In general, sixteen landform elements were identified (Gala, 2001) using a multihierarchical land system approach of land classification (Wielemaker et al.;2001)(Fig. 2). Soils of the study area are predominantly Leptosols, Cambisols, Vertisols, Fluvisols and Nitosols (WRB, 2006) (Gala, 2001; (Fig. 3)) formed by active erosion-accumulation processes and natural regeneration of soils in situ (Nyssen et al.; 2008). Leptosols is a dominant soil on landform elements experiencing active erosion, while Cambisols and Fluvisols are prevalent on gentle slopping lands subjected to colluviums and fluvial deposits. Vertisols is a relatively old soil produced in situ by weathering of parent materials (Gala, 2001). In addition, colluvial, alluvial and fluvial materials have deposited on younger Vertisols on foot-slopes, alluvial fan or floodplains.

\section{Materials and Methods}

\section{Field Land Cover Assessment}

Field assessment for land cover types was conducted from August through October 2000 by visiting 54 different locations. Both visual observations and interviews with local farmers were used to enumerate land cover types. The enumerated land cover data were spatially referenced on 1:50,000 topographic maps for use as ground reference, for training the RS image classifier and as Ground Control Points (GCPs) for image geo-rectification. The land cover assessment and classification was done in close consultation with FAO Land Cover Classification System (LCCS) (FAO, 1997; Di Gregorio and Jansen, 2005).
LANDSAT ETM Data and Image Processing

The LANDSAT ETM data of October 19, 2000 were acquired free of charge from the U.S. Geological Survey (USGS), Earth Resource Observation and Science Center (EROS). The image was selected on the basis of the season of data acquisition, which corresponded with the field assessment period, and based on image quality (cloud free scene). The USGS-EROS processed the image for systemic and terrain induced distortions and delivered it after projecting and referencing to Universal Transverse Mercator (UTM) and World Reference System (WRS), respectively. The geometric integrity of the image was further adjusted to match the soils and landform elements maps. These maps were developed from the topographic map $(1: 50,000)$ that was used as the base map. The GCPs (e.g., hydrographic features, road intersections, parcel corners, rock outcrops, settlements and other unique objects) that were featured on the topographic maps were used for geo-rectification. The image was georectified with a first order polynomial transformation algorithm, and only algorithms performing with errors in the order of 0.5 or less in both Northing and Easting were accepted.

Image Classification and Accuracy Assessment

The first step in supervised image classification is detection and identification of features selected for training the image classifier. For this visual task, a multi-band correlation matrix was constructed to select the image combination that delivers an easily interpretable color composite image.

Accordingly, a band combination of TM4, TM5 and TM3 assigned Red, Green and Blue, respectively was selected for visualization. This band combination showed low correlation and contained a maximum amount of information (Lillesand and Kiefer, 2006).

Visual image interpretation led to the identification of land cover types and hydrological features enumerated during field survey. Approximately 9-13 homogenous training samples were collected for each land cover type and spectral reflectance signature statistics were evaluated for their separability. Statistically separable training samples were used to train a maximum likelihood classification (MLC) algorithm included in ERDAS IMAGINE 9.1 (2006) in order to derive a classified image. 


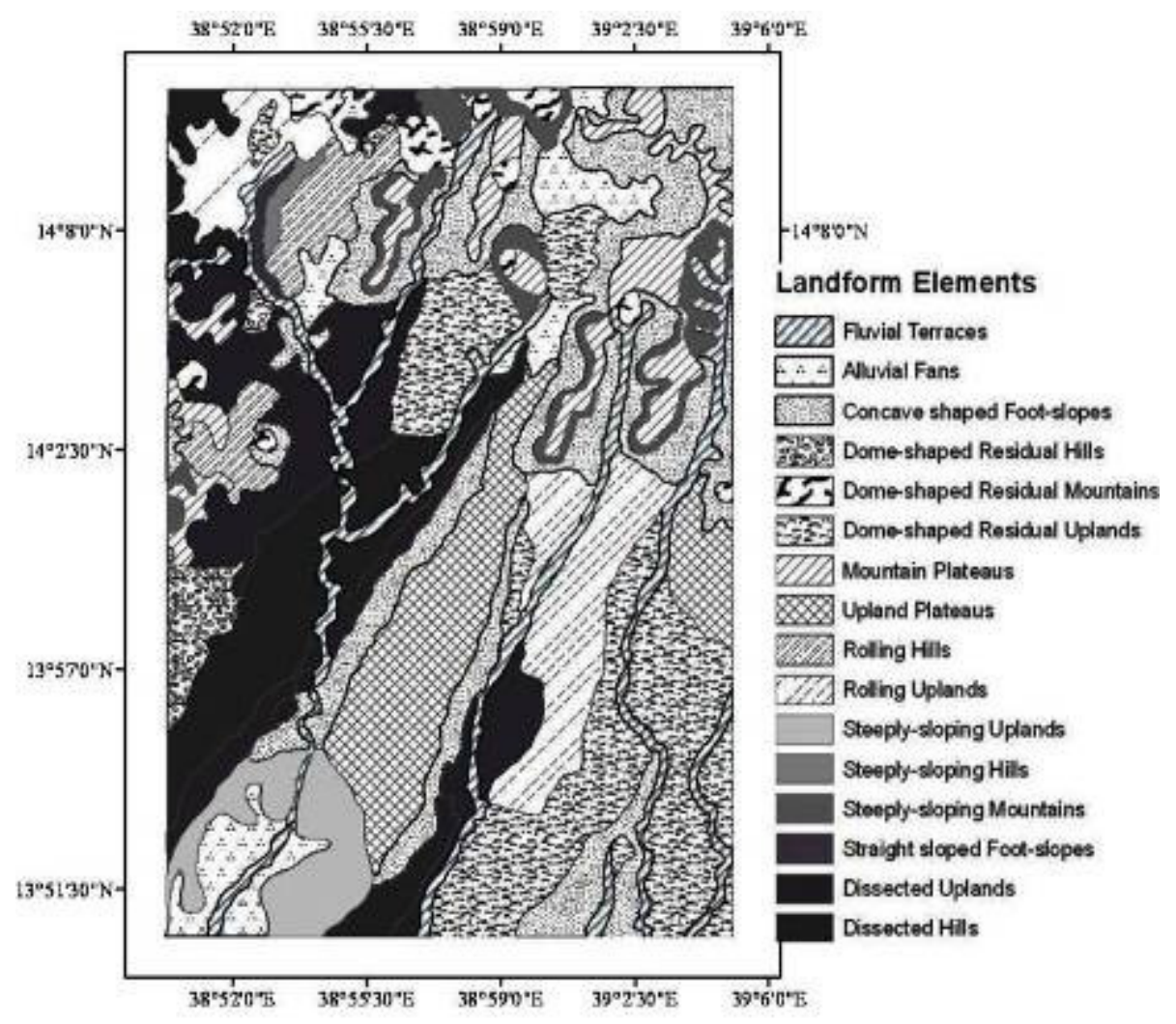

Figure 2: Landform elements map of the Adwa district (adapted from Gala, 2001)

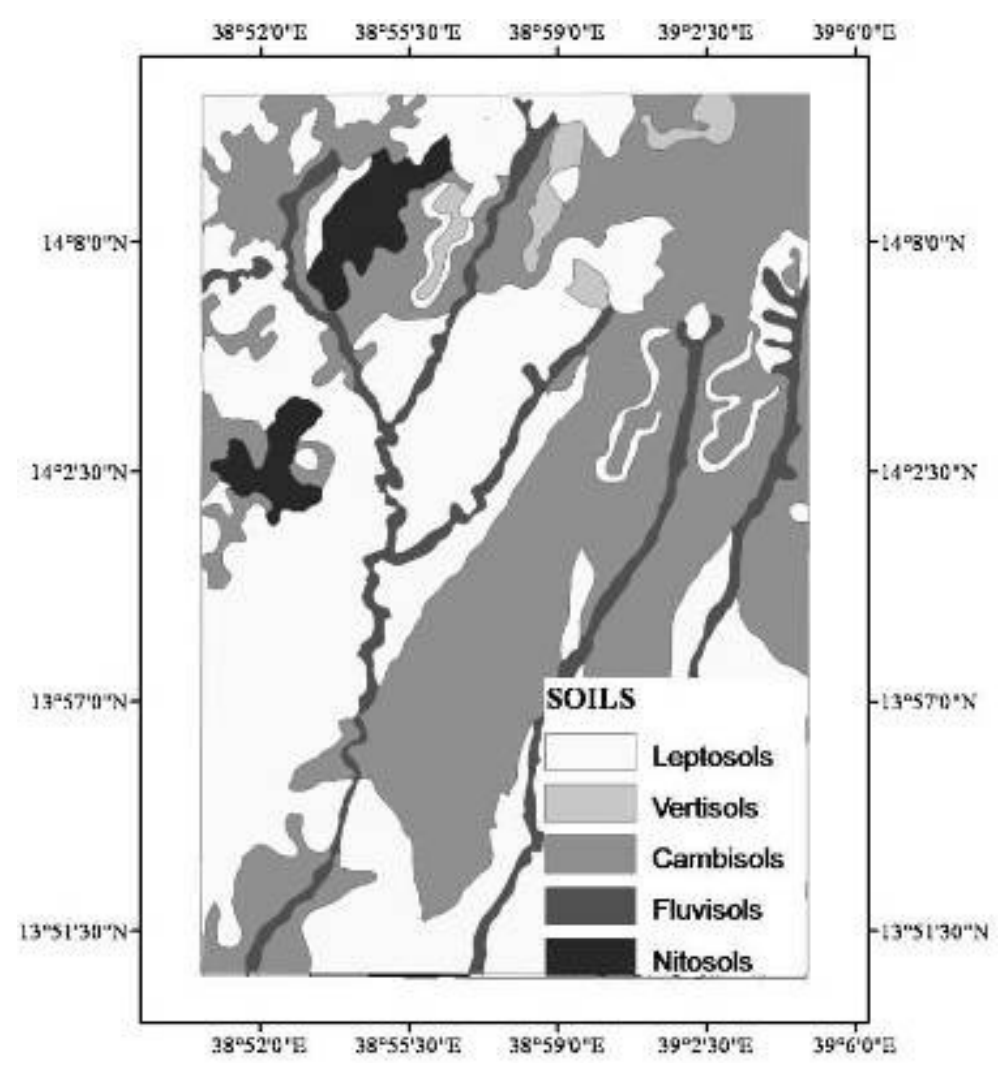

Figure 3: Map of major soils of the Adwa district based on WRB the FAO UNESCO soil classification system (adapted from Gala, 2001). 


\section{Materials and Methods}

Field Land Cover Assessment

Field assessment for land cover types was conducted from August through October 2000 by visiting 54 different locations. Both visual observations and interviews with local farmers were used to enumerate land cover types. The enumerated land cover data were spatially referenced on 1:50,000 topographic maps for use as ground reference, for training the RS image classifier and as Ground Control Points (GCPs) for image geo-rectification. The land cover assessment and classification was done in close consultation with FAO Land Cover Classification System (LCCS) (FAO, 1997; Di Gregorio and Jansen, 2005).

LANDSAT ETM Data and Image Processing

The LANDSAT ETM data of October 19, 2000 were acquired free of charge from the U.S. Geological Survey (USGS), Earth Resource Observation and Science Center (EROS). The image was selected on the basis of the season of data acquisition, which corresponded with the field assessment period, and based on image quality (cloud free scene). The USGSEROS processed the image for systemic and terrain induced distortions and delivered it after projecting and referencing to Universal Transverse Mercator (UTM) and World Reference System (WRS), respectively.

The geometric integrity of the image was further adjusted to match the soils and landform elements maps. These maps were developed from the topographic map $(1: 50,000)$ that was used as the base map. The GCPs (e.g., hydrographic features, road intersections, parcel corners, rock outcrops, settlements and other unique objects) that were featured on the topographic maps were used for georectification. The image was geo-rectified with a first order polynomial transformation algorithm, and only algorithms performing with errors in the order of 0.5 or less in both Northing and Easting were accepted.
Image Classification and Accuracy Assessment

The first step in supervised image classification is detection and identification of features selected for training the image classifier. For this visual task, a multi-band correlation matrix was constructed to select the image combination that delivers an easily interpretable color composite image. Accordingly, a band combination of TM4, TM5 and TM3 assigned Red, Green and Blue, respectively was selected for visualization. This band combination showed low correlation and contained a maximum amount of information (Lillesand and Kiefer, 2006).Visual image interpretation led to the identification of land cover types and hydrological features enumerated during field survey. Approximately 9-13 homogenous training samples were collected for each land cover type and spectral reflectance signature statistics were evaluated for their separability. Statistically separable training samples were used to train a maximum likelihood classification (MLC) algorithm included in ERDAS IMAGINE 9.1 (2006) in order to derive a classified image.

Post-classification processing, accuracy assessment and reclassification were also conducted following the image classification. For the post-classification processing, a 3x3 moving window majority filter operation was used to remove "salt and paper" noise in the classified image. Accuracy assessment was conducted with a conventional error matrix having parameters of user accuracy, producer accuracy, overall accuracy and kappa statistics to measure the accuracy of the classified image. One hundred and fiftythree randomly selected independent points collected during the field survey were used for validating the classification results. The land cover relations with other landscapes attributes were investigated after the mapped land cover was broadly reclassified into five major land cover categories: cultivated land, degraded landscapes, woodlands, grasslands and settlement. 


\section{Relationships among Environmentally Degraded} Landscapes Biophysical Attributes

Both regression and spatial analysis establish relationships between degraded land cover and other attributes of the landscape. However, the application of regression is limited because the relationship among the physical attributes of land and land covers may not be specified as one variable being dependent on the other Alternatively, GIS-based spatial analysis can measure quantitative relationships between landscape attributes, particularly, when results of spatial overlays are linked with other statistical and probabilistic indices (Bayes' conditional probability).

$$
P(A / B)=\frac{P(B / A) * P(A)}{P(B)}, \text { Equation (1) }
$$

Where: $\mathrm{P}(\mathrm{A})$ : probability occurrences of particular land cover types in the district without having any knowledge about soils or landform elements.

P (B): probability occurrences of particular soils or landform elements without having any information about the probability land cover types occurrences, $\mathrm{P}$ (B/A): the conditional probability of soils or landform elements occurrences given the occurrences of a given land cover.;P (A/B): often known as posterior probability and it is the conditional probability of land cover occurrences given the occurrences of soils or landform elements.

Bayes' probability approach (an extension of traditional probability) allows updating the probability attached to the occurrences of a specific event (e.g., land cover types) in light of the occurrences of particular evidence (such as soils or landform elements (Malczewski, 1999). The approach revises traditional probability by incorporating additional evidence or information, which improves predicting the likelihood occurrences of the events (e.g., land cover types). The Bayes' probability was executed on a spreadsheet using a computational equation (1).

\section{Results and Discussion}

The Land Cover Types The field survey for land cover types in the Adwa districts enumerated various land cover types (Fig 4, Table 1). The inventory labeled towns and villages (Adwa, Adi-abune, Yahya, Endabatsehama and Maykinetal) and roads (Asphalt, all weathered and dry weather roads) under the class of built-up lands. Mono cropping, mixed cropping, sequential cropping, wooded farming and agro-forestry were specified under the category of cultivated land. Classes of degraded landscapes included scattered scrubs and shrubs, while relatively dense trees, shrubs and scrubs are classified as woodlands. A class of badlands includes rock outcrops and barren lands lands; while transient and permanent rivers (Ruba Shet, the Kinetal Shet, and Ira Shet) and water reservoirs (Midmier dam) in the district were classified as water bodies. The land cover types enumerated in the district are typical of Northern Ethiopian Highlands (Hadgu, 2008; Tegene, 2002).

The existence of such diverse land cover types in the district reflected important ecological and social attributes of the Ethiopian highlands and the district, in particular. The district has a range of attitudes (from 1500 to $2700 \mathrm{~m}$ asl), which allows the region to have various temperature and rainfall regimes (microclimates). Therefore, the diverse land cover may stem from these microclimates, which have created ecological niches that have sustained various land cover types. In addition, the district had greater potential to support bioproductive land cover types, if not for the immense human induced environmental degradation. Hence, the observed land cover types are perhaps a result of varying degree of human interferences to native vegetation. Agricultural expansion on hilly and rugged terrain to meet the demands of the growing population could have brought deforestation and soil erosion that have caused damage to native vegetation structure (Feoli et al.; 2002; Hadgu, 2008). 
Table 1: Types of land cover types in Adwa-werie district specified during field survey (August - October 2000).

\begin{tabular}{|c|c|c|}
\hline \multirow[t]{2}{*}{ Role No. } & \multicolumn{2}{|r|}{ LULC Types } \\
\hline & Higher Aggregations & Lower Aggregations \\
\hline 1 & Built-up lands & Towns \\
\hline \multirow[t]{4}{*}{2} & & Villages \\
\hline & & Asphalt road \\
\hline & & All Weather road \\
\hline & & Dry weather road \\
\hline 3 & Cultivated Lands & Mono-cropping \\
\hline 4 & & Mixed cropping \\
\hline 5 & & Sequential cropping \\
\hline 6 & & Wooded cropland \\
\hline 7 & & Agro-forestry (Home-gardening) \\
\hline 8 & Grasslands & Natural Grasslands \\
\hline 8 & Degraded Landscapes & Sparse (degraded) Shrubs ( $1-30 \%$ cover and $0.3-5 \mathrm{~m}$ height) \\
\hline \multirow[t]{3}{*}{10} & & Sparse (degraded) Scrubs $(1-30 \%$ cover and $0.3-3 \mathrm{~m}$ height) \\
\hline & & Barren lands \\
\hline & & Rock outcrops \\
\hline 11 & Woodlands & $\begin{array}{l}\text { Closed trees and shrubs }(60-100 \% \text { cover and } 3-30 \mathrm{~m} \text { height }) \\
\text { Closed scrubs }(60-100 \% \text { cover and } 0.3-3 \mathrm{~m} \text { height })\end{array}$ \\
\hline 12 & & Open trees and shrubs $(30-60 \%$ cover and $3-30 \mathrm{~m}$ height $)$ \\
\hline 15 & Water bodies & Artificial water body (Water reservoir (Dam)) \\
\hline 16 & & Natural water bodies (Rivers) \\
\hline
\end{tabular}

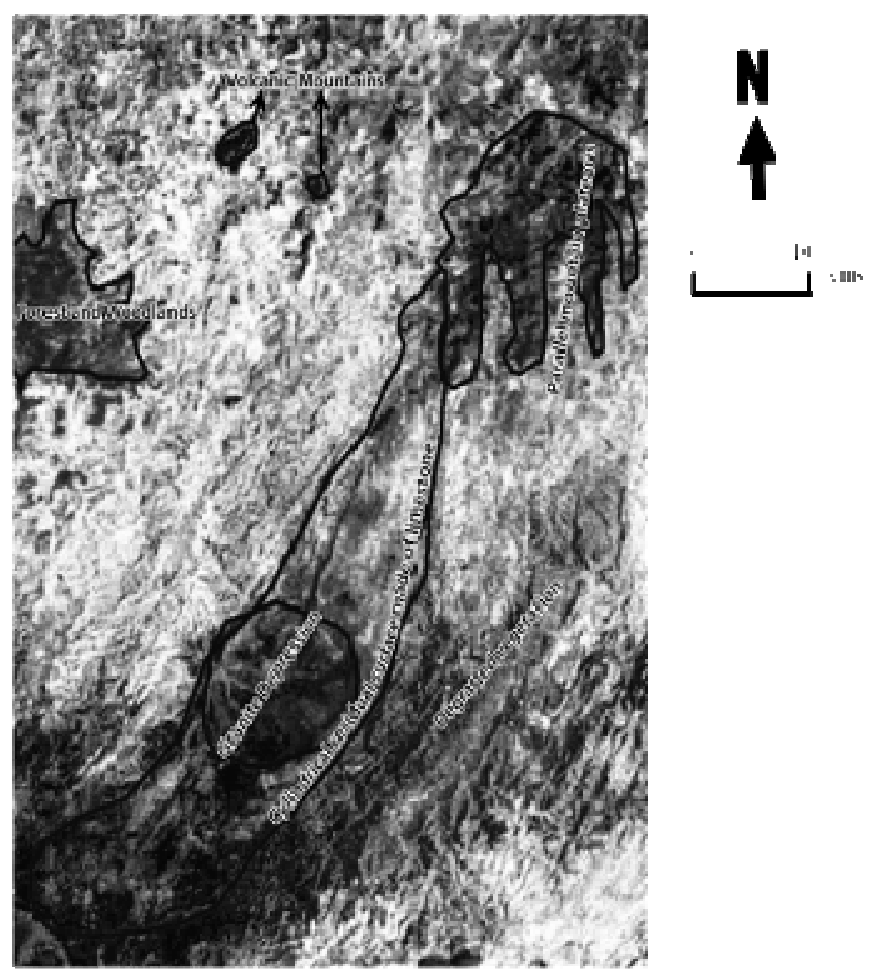

Figure 4: LANDSAT ETM + raw image of 2000 as displayed by TM 4, 5, and 3 in color composite of Red, Green and Blue respectively. 
A LANDSAT ETM + false color composite image arranged in a 4-5-3 RGB (red, green, and blue) band combination has helped the visual recognition and identification of various landscape and land cover features specified during the field survey (Fig. 4). The image displayed district terrain features such as cone shaped volcanic mountains (e.g., Soloda Mountain near the town of Adwa), parallel mountain plateaus, a granite depression and a cylindrical residual surface made of limestone. Additionally, towns (Adwa, and Adiabune), villages (Maykinetal and Indabatseham), roads (e.g., from Adiabune to Enticho, Adwa to Maykinetal) and river systems (e.g., Werie, Asem, Seysa, Ira, Gwahiro and Tse'ediya) were also detectable. With regard to land cover types, none-wooded croplands on rolling hills landscape and wooded croplands along mountain foot-slopes were identified. Extensive grassland (between the towns of Adwa and Adia-bune and on the foot-slope of Soloda Mountain); degraded vegetation (in the southern central and south eastern study area) and woodlands on very steep mountain slopes were also detected. The image also showed barren lands on dissected and residual uplands and hills and rock outcrops at the apex of the domeshaped volcanic mountains. The automated image classification of LANDSAT ETM+ was able to thematically map nine land cover types (with $75 \%$ accuracy and kappa statistics $=0.73$; Fig. 5). Accordingly, the district consisted of non-wooded croplands (24\%), wooded-croplands (8\%), grasslands (3\%), degraded shrublands (24\%), degraded scrublands $(5 \%)$, rock outcrops $(2 \%)$ and barren lands $(7 \%)$, woodlands $(26 \%)$ and scrublands $(1 \%)$. The degraded landscapes (i.e., scattered shrubs and scrubs; barren lands and rock outcrops) stretched over $37 \%$ of the study area, while $32 \%$ of the district was cultivated lands (i.e., nonwooded and wooded croplands). The remaining portions of the district were woodlands and grasslands.The arable farming dominated areas were closer to the main settlement areas (e.g., town of Adwa) while forests and woodlands covered the southern and northeast regions of the district. The wooded-croplands were found as a transition from non-wooded croplands to woodlands while barren lands occupied the central and south central part of the study area. Rock outcrops were found as patches close to settlements in the northeastern and southern parts of the study area. The LANDSAT ETM+ data was only partially successful in mapping the land cover types enumerated via field survey (Fig. 5). The main reason was that the spectral signature statistics of the training samples were overlapping for some land cover types. For example, the signature statistics of training samples for mono cropping, sequentialcropping and mixed-cropping were inseparable and therefore lumped into the class non-wooded cropland. Additionally, wooded-farming and agro-forestry had identical signature statistics and hence were combined into a category of wooded croplands. The spectral characteristics of settlement areas were indistinguishable from non-used barren lands. Consequently, settlement areas were delineated on the topographic map and added to the classified image. Despite these limitations, LANDSAT ETM+ data has distinguished the major land cover types, which is consistent with the capability of LANDSAT ETM data demonstrated elsewhere for mapping and monitoring land cover of environmentally degraded landscapes (Metternicht et al.; 2009; Lu et al.; 2007; and Zhang et al.; 2005).

The percent natural woodland (26\%) discovered in the district is also comparable to, or slightly higher than, the national average of 22\% (Bishaw, 2001). This is perhaps because the district is very mountainous and has many escarpments, which may have mitigated agricultural expansion and other woodland exploitation by humans (Woldu, 1999; Zhang et al.; 2005). The percent could also be affected by the growing season when the image was taken. We noted however that percent agricultural land use (32\%) and degraded landscape $(37 \%)$ were far larger than the respective national average of $12 \%$ and $7 \%$ (27\% on the highlands) (Hawando, 1997; WRI, 2003) indicating extensive agricultural expansion and subsequent land degradation in the district. 


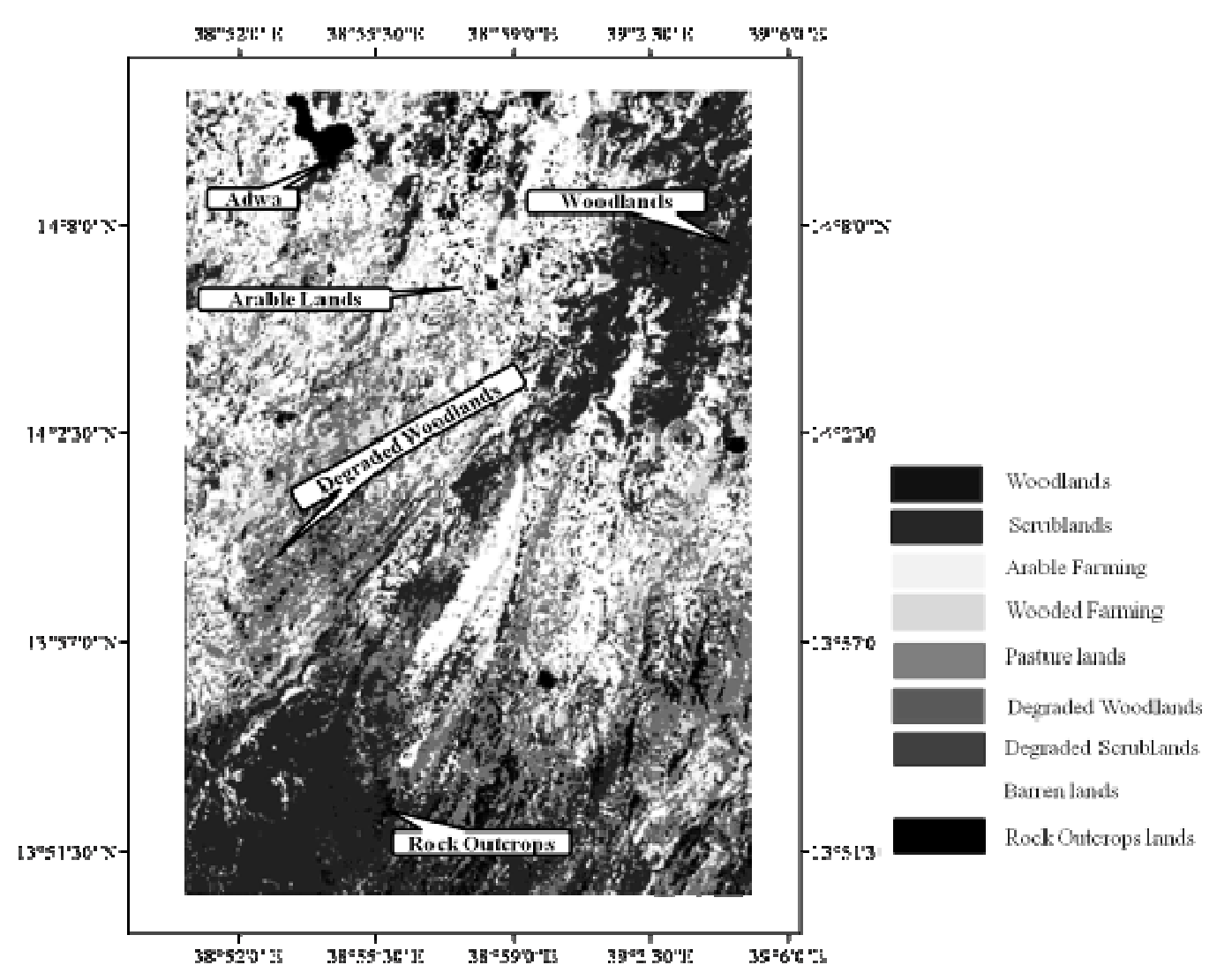

Figure 5: The land cover map of the Adwa district obtained from the classification result of LANDSAT image 2000

\section{Relationship of Land Covers Types with other Landscape Attributes}

\section{LULCs Relations with Soils}

A graph of the spatial distribution of land cover by soil type (Fig. 6) has revealed a unique pattern of land cover distribution among major soils. The dominant $(43 \%)$ major soil grouping (Leptosols) supported a majority of land cover types $(60 \%$ of degraded shrubs and scrubs land, $59 \%$ of grasslands, $36 \%$ of woodlands and $26 \%$ of cultivated land) in the district. The second major soil type (Cambisols) supported $44 \%$ of woodland, $43 \%$ of cultivated lands and $34 \%$ of grasslands. On the other hand, the other three major soil types (Nitosols, Fluvisols and Vertisols) contained marginal proportions (1 to $15 \%$ ) of the district's LULC types (Fig. 6).

The dominance of Leptosols soil is a testimony of the district's active soil degradation. Leptosols are characterized by a shallow soil often found on a complex terrain, over bedrock, and where soil erosion exceeds rate of soil formation (ISSS working group $\mathrm{RB}$, 1998). The soil is infertile (due to erosional wash of top fertile soils) and has poor moisture storage capacity (because of shallow soil depth). As a consequence, it could sustain mainly degraded vegetation and short grasses (Drissen and Dudal, 1991; FAO, 2006).

The posterior probability analysis of biophysical attributes of degraded lands has also uncovered a distinct relationship between soils and land cover types (Table 2). The association between cultivated lands (non- 
wooded and wooded croplands) and soil types such as Vertisols (63\%), Fluvisols (47\%), and Cambisols (37\%) soil groupings were strong, while the woodlands were more associated with Cambisols (37\%) and Nitosols (30\%). The degraded landscapes were associated with the occurrence of the Leptosols (49\%). Conversely, cultivated lands were least associated with Leptosols (21\%), while degraded landscapes and woodlands were least associated with Vertisols (11\%) and Fluvisols $(17 \%)$. The soils- land cover relation suggested that Vertisols is the most preferred soil type for cultivation, followed by Fluvisols, while
Leptosols is the least preferred. Vertisols is perhaps preferred because of its high cation exchange capacity and base saturation (Driessen and Dudal, 1991) while the combination of shallow rooting depth $(<10 \mathrm{~cm})$, steep slopes and poor fertility have made Leptosols the least preferred soil for cultivation. Additionally, the agricultural competition for fertile and deep soils (Vertisols and Fluvisols) may have pushed woodlands to other deep but relatively less fertile soils (Cambisols and Nitosols).

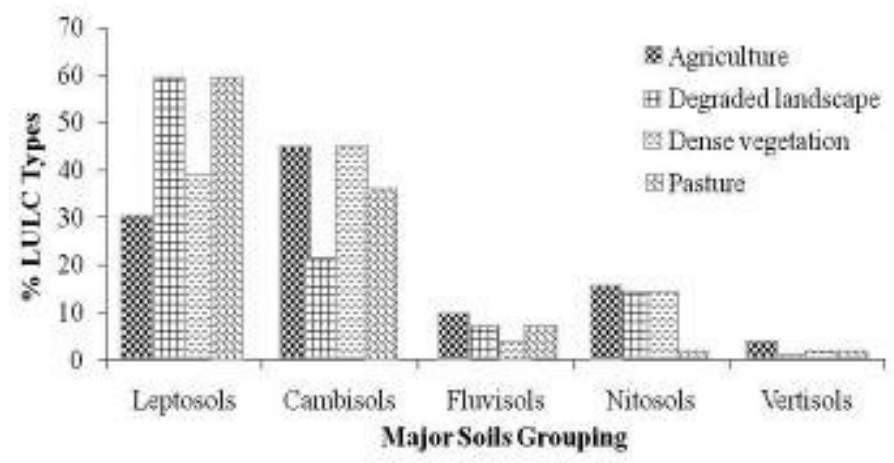

Figure 6: The percent (\%) land cover type for each major soil groupings (FAO classification) of the district.

Similar findings were also reported on other Ethiopian highlands (Nyssen et al.; 2008). Neyssen et al. (2008) noted that Vertisols were exclusively used for crop production in May Zegzeg catchment, near Hagere Selam in northern Ethiopia, whereas rangelands and area exclosures were associated with shallow Leptsols and infertile Regosols (Nyssen et al.; 2008).

\section{LULC Relations with Land Elements}

A graph of basic spatial overlay analysis of major landforms and land cover (Fig. 7) has also revealed the pattern of land cover distribution within major landforms of Mountains, Hills, Uplands, Foot-slopes and Fluvial (Table 3). The majority of land cover types showing signs of degradation (54\%) were in uplands, which is also the dominant (46\%) landform type of the district. Additionally, the uplands also had a sizeable proportion of cultivated lands (39\%), grasslands (47\%) and woodland $(43 \%)$. On the other hand, mountainous landforms supported a small amount of cultivated lands $(8 \%)$ and grasslands $(5 \%)$ while hills and fluvial landforms constituted the least woodlands $(11 \%)$ and degraded landscapes $(6 \%)$.

Specific associations of landform - land cover relations were also revealed by posterior probability analysis. Woodlands were strongly (46\%) associated with mountain landforms followed by fluvial (Table 3), particularly, with steeply slopping areas of the mountains (Table 4). Conversely, they were least (16\%) associated with hilly landforms (Table 3), notably, the residual dome-shaped (8\%) and rolling (5\%) landscape of the hilly landforms (Table 5). Cultivated lands were substantially associated (49\%) with foot-slopes of mountains, hills and uplands, followed by fluvial landforms (Table 3). They were particularly occurring on concaved-shaped foot-slopes $(51 \%)$ that consisted of colluviums made-up of volcanic (Trachytes, basalt and phenoline) and low metamorphic rock rich in Schist, Phyllite and metavolcanite (Table 7). 
Cultivated lands occur the least on mountainous landforms (25\%; Table 3) particularly with dome-shaped residual surfaces of mountains (2\%) (Table 4).

Finally, degraded landscapes (i.e., scattered shrubs and scrubs, barren-lands and rock outcrops) were strongly associated (48\%) with hills followed by upland landforms (Table 3). In the hilly landforms, the greatest association was detected on dissected (59\%) and domeshaped residual (49\%) land elements (Table 5) while dissected land element showed greater association (56\%) with the uplands (Table 6). Degraded landscapes were least prevalent on foot slopes $(23 \%)$ and fluvial (20\%) landforms, particularly on straight sloping areas of foot-slopes (7\%) and alluvial fans (10\%) of fluvial landforms (Table 7).

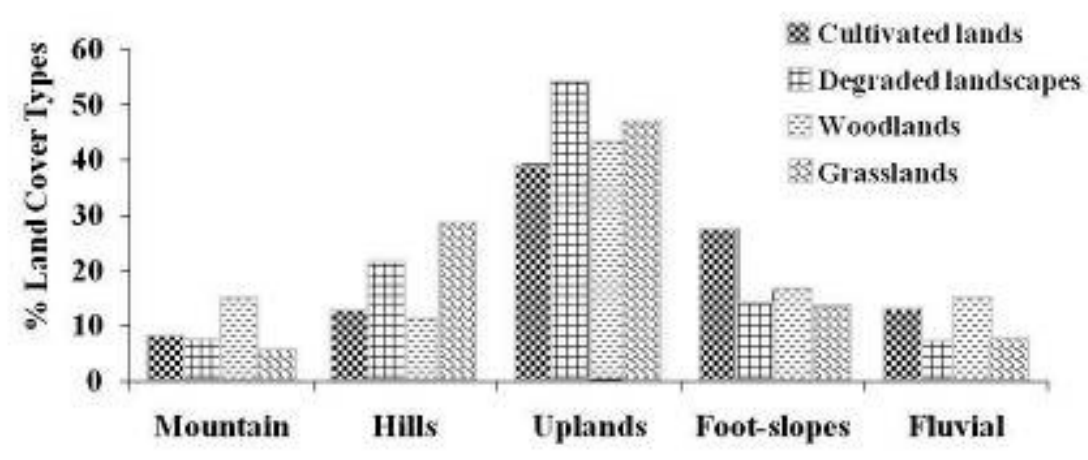

Major Landforms

Figure 7: The percent $(\%)$ land cover type for each major landforms of the district.

The relationship between land cover types and physical attributes of environmentally degraded landscapes suggested that landform characteristics control the land cover distribution in the district. For instance, the occurrences of woodlands on the mountain, particularly the steep-sloping areas, could be evidence of remnant natural woodlands due to historical inaccessibility and remoteness (Woldu, 1999, Feoli et al.; 2002a). In addition, the association with fluvial landforms can be attributed to riparian vegetation along or within the banks of the permanent or ephemeral rivers.

The dominance of crop production on the foot-slope and fluvial landforms pointed the suitability of these landform elements having low topography experiencing minor losses of fertile top soils through erosion (Fetien et al.; 1999). Besides, the topography has enabled the parent material to be on the landscape long enough for undergoing physical and chemical weathering to release nutrients for plant growth. Moreover, the land elements continuously receive fresh soil sediments from nutrient rich parent material of the surrounding higher ground through gravo-fluvial processes.
Consequently, they had fertile soils characterized by deeper rooting and higher water storage. On the other hand, the wooded croplands observed on the foot-slopes are from multi-purpose trees and shrubs that were planted to stabilize physical structures. The physical structures were constructed to intercept run-off and subsequent soil erosion (Fetien et al.; 1999).

Lastly, the associations between degraded landscapes (scattered shrubs and scrubs; barren land and rock-outcrops) and dissected uplands and hills are possibly because of severe erosion that hampered soil development on these landform elements. Soils were shallow (i.e. low water storage capacity) and infertile, having limited the capability to support land cover types other than degraded or no vegetation.

\section{Recommendations}

The relationships observed among biophysical attributes of environmentally degraded lands present a prospect of guiding sustainable use and rehabilitation of the district's land resources. 
Approximately, one-third of Vertisols and half of Fluvisols soils are suitable for cultivation but not yet cultivated. Additionally, there are topographically suitable land units (i.e., two-thirds of fluvial landforms and half of foot-slopes) were not cultivated. Therefore, there is a possibility of expanding agriculture to these suitable areas and meet food demands of the growing population of the district without causing serious damage to soils and lands. However, there are reasons why these areas have not been used hitherto. These areas are remote and distant from population settlement and inhospitable due to widespread malaria incidence (personal communication). Some areas are also fragmented by gully incision that the practice of long-established farming systems is impracticable. Therefore, the district's land development program should consider these factors when exploring development opportunities for the district.

On the other hand, signs of inappropriate land use practices are also evident. Cultivation has encroached into soils and lands that are already degraded. Approximately, a fifth of Leptsols soil, dissected hills and uplands and steeply slopping mountains; and a third of eroded and dome-shaped residual surfaces of uplands are under cultivation. These are degraded and resource-poor lands and cultivating the lands would provide only a marginal return while accelerating soil erosion and subsequent land degradation. Therefore, the district's land rehabilitation programs should restrict cultivation on these lands, and instead, implement area closures (Mekuria et al.; 2007); off-farm activities (Teketay, 2001); resettlement (to resource rich areas) (Feoli et al.; 2002b); and adopt intensive soil conservation measures (Esser et al.; 2002) recommended elsewhere.

\section{Conclusion}

Adwa district consists of various land cover types with important implications for rehabilitation of environmentally degraded
Ethiopian Highlands. The diverse land cover suggested land bio-productivity potential and a gradient in the intensity of human interference with native vegetation. It also implied ranges of alternative land cover types that can be adopted in the rehabilitation programs for the district's degraded landscapes.

LANDSAT ETM+ data was fairly effective for distinguishing the major land cover types enumerated in the field. Accordingly, non-wooded and wooded croplands, grasslands, degraded shrublands and scrublands, barren-land, rock outcrops, woodlands and settlement were isolated as thematic map categories (classes). Exceptions were observed for some land cover types (mono-cropping, mixed cropping) showing similar spectral characteristics, which made the spectral signature statistics of their training pixels inseparable. However, the demonstrated capability of RS data highlighted the need to adapt LANDSAT ETM and similar data for inventorying and monitoring environmentally degraded lands of the Ethiopian Highlands.

Soils and physiographic attributes of the district's lands exerted a control on land cover distribution. Cultivated lands dominated Vertisols soil and foot-slopes of Mountain and Hill landforms. The fertility of Vertisols and the low topography of foot-slopes attracted the crop production in the district. On the other hand, degraded land cover types were associated with the occurrence of the Leptosols and dissected uplands and hills. The remnants of natural woodlands mainly dominated mountainous landforms due to their inaccessibility and remoteness.

These associations have management implications. They have revealed underutilized areas having suitable soil types, and land units that present an opportunity for agricultural development. Also, they have revealed inappropriate land use on vulnerable soils/lands where instead, exclosure or intensive soil conservation practices should be implemented. 


\section{References}

Aynekule E., Wubneh, W., Birhane, E. and Begashaw, N. (2006). Monitoring and evaluating land use/land cover change using participatory Geographic information system (PGIS) tools: A case study of Begasheka Watershed, Tigray, Ethiopia. EJISDC 25(3): 110.

Bewket, W. (2002). Land cover dynamics since 1950s in Chemoga watershed, Blue Nile basin, Ethiopia. Mountain Research and Development, 229(3):263-269.

Berry, L. (2003). Land degradation in Ethiopia: Its extent and Impact. Commissioned by the GM with WB support.

Bishaw, B. (2001). Deforestsation and land degradation in the Ethiopian highlands: A strategy for Physical Recovery. Northeast African Studies, 8(1):7-26.

Drissen, F.M. and Dudal, R . (1991). The major soils of the world - lecture notes on their geography, formation, properties and use. Wageningen University and Katholieke Universiteit Leuven: Koninklijke Wohrmann BV Zutphen, The Netherlands.

Di Gregorio,,A., \& Jansen, L.J.M. (2005). The Land Cover Classification System: Classification concepts and user manual. Rome: Food and Agriculture Organization of the United Nations.

Dubale, P. (2001). Soil and water resources and degradation factors affecting productivity in Ethiopian highlands agro-ecosystems. Northeast African Studies, 8(1):27-52.

EFAP. (1994). Ethiopian forestry action plan: The challenge for development. Addis Ababa, Ethiopia: Ministry of natural resource conservation and development.

ERDAS IMAGINE 9.1 (2006). Leica geosystems geospatial imaging, Norcross, GA, USA

Esser, K., Vagen, G.T. and Haile, M. (2002). Soil conservation in Tigray, Ethiopia. Noragric report no. 5 .

Eweg, H.P.A., van Lammeren, R., Deurloo H. and Woldu, Z (1998). Analyzing degradation and rehabilitation for sustainable land management in the highlands of Ethiopia. Land Degradation and Development, 9:529542.
FAO. (1997). Africover Land Cover Classification. Rome: Food and Agriculture Organization of the United Nations.

FAO. (2006). World reference base for soil resources: A framework for international classification, correlation and communication. Rome: Food and Agriculture Organization of the United Nations.

Fetien, A., Waters-Bayer, A. and Haile M. (1999). Traditional practices and farmers' innovations in land husbandry. Some examples from Tigray, Ethiopia. In Land Husbandry in the Highlands of Ethiopia, Ewnetu Z, Haile M, Gebrehiwot K (eds). Proceedings of a workshop. Vol. II. Mekelle Ethiopia: Mekelle University College, pp49-56.

Feoli, E., Vuerich, L.G. and Woldu, Z. (2002a). Processes of environmental degradation and opportunities for rehabilitation in Adwa, Northern Ethiopia. Landscape Ecology, 17:315-325.

Feoli, E., Vuerich, L.G. and Woldu, Z. (2002b). Evaluation of environmental degradation in northern Ethiopia using GIS to integrate vegetation, geomorphological, erosion and socio-economic factors. Agriculture, Ecosystem and Environment, 91:313-325.

Gala, T.S. (2001). Land resources analysis to support land use decisions: the case of Tigray Region, Northern Ethiopia. (MSc thesis), Netherlands: Wageningen University.

Gamachu, D. (1977). Aspects of climate and water budget in Ethiopia. Addis Ababa: Addis Ababa University press.

Hadgu, K.M. (2008). Temporal and spatial changes in land use patterns and biodiversity in relation to farm productivity at multiple scales in Tigray, Ethiopia. (PhD Dissertation), Netherlands: Wageningen University.

Hawando, T. (1997). Desertification in Ethiopian highlands. Rala Report No. 200.

Hurni, H. (1988). Degradation and conservation of the resources in the Ethiopian highlands. Mountain Research and Development, 8(2/3):123-130.

ISSS working group RB. (1998). World reference base for soil resources: Introduction (JA Deckers, FO Nachtergaele and OC Spaargaren, eds). First Edition. International Society of Soil Science (ISSS), international 
soil references and information center (ISRIC) and Food and Agriculture Organization of the United Nations (FAO), ACO Leuven. pp. 9599.

Lillesand, T.M. and Kiefer, W.R . (2006). Remote sensing and image interpretation. New York: John Wily \& Sons, Chapters $1 \& 8$.

Lu, D., Batistella, M., Mausel, P. and Moran, E. (2007). Mapping and Monitoring land degradation risks in the western brazillian amazon using multi-temporal landsat TM/ETM + images. Land degradation and development, 18:41-54.

Malczewski, J. (1999). GIS and multi-criteria decision analysis. New York, NY: John Wiley and Sons, pp. 124-129.

Mekuria, W. E., Veldkamp, E., Haile, M., Nyssen, J. B., Muys, B. and Gebrehiwot, K. (2007). Effectiveness of exclosures to restore degraded soils as a result of overgrazing in Tigray, Ethiopia. Journal of Arid Environment, 69(2):270-284.

Metternicht, G., Zinck, J.A., Blanco, P.D. and del Valle, H.F. (2009.) Remote sensing of land degradation: experiences from Latin America and the Caribbean. Journal of Environmental Quality, 39:42-61.

Nyssen. J., Naudts, J., De Geyndt, K., Haile, M., Poesen, J., Moeyersons, J., Deckers, J. (2008). Soils and land use in the Tigray highlands (northern Ethiopia). Land Degradation and Development, 19:257-274.

Nyssen. J., Van dernreylen, H., Poesen, J., Moeyersons, J., Deckers, J., Haile, M. Salles, C., and Govers, G. (2005). Rainfall erosivity and variability in the northern Ethiopian highlands. Journal of Hydrolog,y 311(14): $172-187$.

Nyssen. J., Haile, M., Moeyersons, J., Poesen, J., Deckers, J. (2000). Soil and water conservation in Tigray (Northern Ethiopia): The traditional daget technique and its integration with introduced techniques. Land degradation and development, 11:199-208.

\section{Acknowledgement}

This work was supported by SURISE project funded by the European Union and a scholarship granted by the Netherlands Organization for International Cooperation (NUFFIC). U.S. Geological Survey (USGS), Earth Resource Observation and Science Center (EROS), free of charge, provided preprocessed LANDSAT ETM data for this study. The lead author wishes to thank Wageningen University-Laboratory of Geo-information sciences; Mekelle University and Adwa District's Department of Natural Resources for allowing him use their research facilities and providing logistics necessary for field works. The authors acknowledge the support of the University of Western Ontario, London, Ontario, Canada.
Raina, P., Joshi, D.C. and Kolarkar, A.S. (1991). Land degradation mapping by remote sensing in the arid region of India. Soil Use and Management 7(1): 47-52.

Tegene, B. (2002). Land-cover/land use changes in the Derekolli catchment of the south welo zone of Amhara Region, Ethiopia. EASSRR 26(1):1-20.

Teketay, D. (2001) Deforestation, wood famine and environmental degradation in Ethiopian highlands Ecosystems: Urgent need for action. Northeast African Studies, 8(1):5376.

Tekle, K. and Hedlund, L. (2000). Land cover changes between 1958 and 1886 in Kalu district, southern Wello, Ethiopia. Mountain Research and Development, 20(1):42-51.

Van de Wauw, J., Baert, G., Moeyersons, J., Nyssen, J., De Geyndt, K., Taha, N., Zenebe, A., Poesen, J. and Deckers, J. (2008). Soillandscape relationships in the basalt-dominated highlands of Tigray, Ethiopia. Catena, 75:117127.

Wielemaker, W.G. De Bruin, Epema, G.F. and Veldkamp, A. (2001). Significance and application of the multi-hierarchical land system in soil mapping. Catena Journal $\mathbf{4 3}$ (2001) 15-34, Wageningen University, Netherlands.

Woldu, Z. (1999) Rehabilitation of fragmentation in Tigray. In Land Husbandry in the Highlands of Ethiopia, Ewnetu Z, Haile M, Gebrehiwot $\mathrm{K}$ (eds). Proceedings of a workshop. Vol. II. Mekelle University College: Mekelle, Ethiopia.

WRI. (2003). World Resource Institute-earth trend/environmental information Ethiopia. http://earthtrends.wri.org/pdf_library/country_ profiles/for_cou_231.pdf.

Zhang, Q., Devers, D., Desch, A., Justice, C.O. and Townshend, J. (2005). Mapping tropical deforestation in central Africa. Environmental Monitoring and Assessment 101:69-83. 
Table 2: The associations between the major soil groups and land cover types of Adwa district, northern Ethiopia.

\begin{tabular}{|c|c|c|c|c|c|c|}
\hline \multirow[t]{2}{*}{ Land cover types } & \multicolumn{6}{|c|}{$P(l c / s g)$} \\
\hline & Leptosols & Cambisols & Fluvisols & Nitosols & Vertisols & $P(l c)$ \\
\hline Cultivated land & 21 & 37 & 47 & 34 & 63 & 31 \\
\hline Degraded landscape & 49 & 21 & 32 & 36 & 11 & 36 \\
\hline Woodlands & 25 & 37 & 18 & 30 & 23 & 30 \\
\hline Grasslands & 4 & 3 & 3 & 0 & 3 & 3 \\
\hline Settlement & 0 & 1 & 1 & 0 & 0 & $\mathbf{1}$ \\
\hline$P(s g)$ & 43 & 36 & 6 & 13 & 2 & 100 \\
\hline
\end{tabular}

Table 3: Relationship between the major landforms and land covert types of Adwa district, northern Ethiopia.

\begin{tabular}{|c|c|c|c|c|c|c|}
\hline \multirow[b]{2}{*}{ Land cover types } & \multicolumn{6}{|c|}{$P(l c / l f)$} \\
\hline & Mountain & Hills & Uplands & Foot-slopes & Fluvial & $\mathbf{P}($ wv $)$ \\
\hline Cultivated lands & 26 & 28 & 27 & 48 & 36 & 32 \\
\hline Degraded landscapes & 26 & 45 & 40 & 23 & 20 & 34 \\
\hline Woodlands & 46 & 21 & 28 & 27 & 42 & 30 \\
\hline Grasslands & 2 & 7 & 4 & 5 & 3 & 4 \\
\hline Settlement & 0 & 0 & 1 & 0 & 0 & 1 \\
\hline$P(l f)$ & 10 & 15 & 46 & 18 & 11 & 100 \\
\hline $\begin{array}{l}P(l f)= \\
P(l c)= \\
P(l u / l f \\
\text { with the }\end{array}$ & $\begin{array}{l}\text { ility of maj } \\
\text { ilitity of ma } \\
\text { pability by } \\
\text { rences of th }\end{array}$ & $\begin{array}{l}\text { andfor } \\
\text { land ce } \\
\text { ch the } \\
\text { lajor la }\end{array}$ & $\begin{array}{l}\text { ypes; } \\
\text { rence of } \\
\text { ms. }\end{array}$ & cular land co & is ass & \\
\hline
\end{tabular}

Table 4: Association between the land elements of mountainous landforms and land cover types of Adwa district, northern Ethiopia.

\begin{tabular}{ccccc}
\hline \multirow{2}{*}{ Land cover types } & \multicolumn{4}{c}{$\boldsymbol{P}(\boldsymbol{l c} / \boldsymbol{m} \boldsymbol{l f})$} \\
& $\begin{array}{c}\text { Mountainous } \\
\text { Plateau }\end{array}$ & $\begin{array}{c}\text { Dome-shaped } \\
\text { Mountains }\end{array}$ & $\begin{array}{c}\text { Steeply-sloping } \\
\text { Mountains }\end{array}$ & $\boldsymbol{P}(\boldsymbol{l c})$ \\
\cline { 2 - 5 } & 35 & 2 & 20 & $\mathbf{2 6}$ \\
Cultivated lands & 18 & 73 & 23 & $\mathbf{2 7}$ \\
Degraded landscapes & 50 & 21 & 56 & $\mathbf{4 5}$ \\
Woodlands & 2 & 4 & 2 & $\mathbf{2}$ \\
Grasslands & 0 & 0 & 0 & $\mathbf{0}$ \\
Settlement & $\mathbf{6 1}$ & $\mathbf{1 5}$ & $\mathbf{2 5}$ & $\mathbf{1 0 0}$ \\
$\boldsymbol{P}(\boldsymbol{m} \boldsymbol{l} \boldsymbol{f})$ & & &
\end{tabular}

$P(l f)=$ probability of major landforms;

$P(l c)=$ probability of major land cover type;

$P(l u / m l f)=$ Probability by which the occurrence of a particular land cover type is associated with the occurrence of the mountainous landforms. 
Table 5: Relationship between the land elements of hilly landforms and land cover types of Adwa district, northern Ethiopia.

\begin{tabular}{cccccc}
\hline \multirow{2}{*}{ LULC Types } & \multicolumn{5}{c}{$P(l c / h l f)$} \\
\cline { 2 - 6 } & $\begin{array}{c}\text { Dome-Shaped } \\
\text { Hills }\end{array}$ & $\begin{array}{c}\text { Rolling } \\
\text { Hills }\end{array}$ & $\begin{array}{c}\text { Steeply Sloping } \\
\text { Hills }\end{array}$ & $\begin{array}{c}\text { Dissected } \\
\text { Hills }\end{array}$ & $P(l c)$ \\
\hline Cultivated land & 34 & 68 & 14 & 18 & $\mathbf{3 0}$ \\
Degraded landscapes & 49 & 20 & 7 & 59 & $\mathbf{4 8}$ \\
Woodlands & 8 & 5 & 36 & 18 & $\mathbf{1 5}$ \\
Grasslands & 10 & 7 & 42 & 0 & $\mathbf{7}$ \\
Settlement & 0 & 0 & 0 & $\mathbf{6 6}$ & $\mathbf{1 0 0}$ \\
$P(h l f)$ & $\mathbf{1 1}$ & $\mathbf{2 0}$ & $\mathbf{4}$ & & \\
\hline$P(h l f)=$ probability of hilly landforms; & & & \\
$P(l c)=$ probability of major land cover; & & &
\end{tabular}

Table 6: Association between the land elements of upland landforms and land cover types of Adwa district, northern Ethiopia.

\begin{tabular}{|c|c|c|c|c|c|c|}
\hline \multirow[b]{2}{*}{ Land Cover Types } & \multicolumn{5}{|c|}{$P(l c / u l f)$} & \multirow[b]{2}{*}{$P(l c)$} \\
\hline & $\begin{array}{c}\text { Dome- } \\
\text { Shaped } \\
\text { Uplands }\end{array}$ & $\begin{array}{c}\text { Dissected } \\
\text { Uplands }\end{array}$ & $\begin{array}{l}\text { Steeply- } \\
\text { Sloping } \\
\text { uplands }\end{array}$ & $\begin{array}{l}\text { Rolling } \\
\text { Uplands }\end{array}$ & $\begin{array}{l}\text { Uplands' } \\
\text { Plateau }\end{array}$ & \\
\hline Cultivated lands & 36 & 21 & 4 & 51 & 32 & 28 \\
\hline Degraded landscapes & 33 & 56 & 7 & 23 & 50 & 42 \\
\hline Woodlands & 28 & 19 & 89 & 14 & 14 & 25 \\
\hline Grasslands & 1 & 5 & 0 & 5 & 3 & 4 \\
\hline Settlement & 0 & 0 & 0 & 7 & 1 & 1 \\
\hline$P(u l f)$ & 16 & 53 & 9 & 19 & 4 & 100 \\
\hline $\begin{array}{l}P u(l f) \\
P(l c) \\
P(l u / l \\
\text { the oc }\end{array}$ & $\begin{array}{l}\text { obability } \\
\text { bability o } \\
\text { Probabilit } \\
\text { nces of the }\end{array}$ & $\begin{array}{l}\text { pland landfo } \\
\text { ajor LULC; } \\
\text { y which the } \\
\text { land landfor }\end{array}$ & rence of & icular LU & pe is asso & d with \\
\hline
\end{tabular}

Table 7: Relationship between the land elements of depositional landforms and land cover types of Adwa district, northern Ethiopia.

\begin{tabular}{cccccc}
\hline \multirow{2}{*}{ Land Cover Types } & \multicolumn{3}{c}{$\boldsymbol{P}(\boldsymbol{l c} / \boldsymbol{d l f})$} & & \\
\cline { 2 - 5 } & $\begin{array}{c}\text { Concave shaped } \\
\text { foot slopes }\end{array}$ & $\begin{array}{c}\text { Straight sloped } \\
\text { foot-slope }\end{array}$ & $\begin{array}{c}\text { Fluvial } \\
\text { terraces }\end{array}$ & $\begin{array}{c}\text { Alluvial } \\
\text { fans }\end{array}$ & $\boldsymbol{P}(\boldsymbol{l c})$ \\
\hline Cultivated lands & 51 & 38 & 44 & 28 & $\mathbf{4 5}$ \\
Degraded landscapes & 25 & 7 & 29 & 10 & $\mathbf{2 2}$ \\
Woodlands & 22 & 54 & 23 & 59 & $\mathbf{3 1}$ \\
Grasslands & 3 & 1 & 3 & 3 & $\mathbf{2}$ \\
Settlement & 0 & 0 & 0 & $\mathbf{0}$ \\
$\boldsymbol{P}(\boldsymbol{d} \boldsymbol{l} \boldsymbol{f})$ & $\mathbf{5 7}$ & $\mathbf{6}$ & & $\mathbf{1 7}$ & $\mathbf{1 0 0}$ \\
\hline
\end{tabular}

$P(d l f)=$ probability of depositional landforms;

$P(l c)=$ probability of major land cover;

$P(l c / d l f)=$ Probability by which the occurrence of a particular land cover type is associated with the occurrences of the depositional landforms. 